Thus, at present, chronic mild viral infection of the liver may be the price paid for better survival of the graft in patients with transplants in whom immunosuppression is effective.

${ }^{1}$ Sopko, J, and Anuras, S, American fournal of Medicine, 1978, 64, 139

2 Anuras, S, et al, Archives of Internal Medicine, 1977, 137, 42.

3 Ware, A J, et al, Gastroenterology, 1975, 68, 755.

${ }^{4}$ Degos, F, et al, Italian fournal of Gastroenterology, 1978, 10, 4.

${ }_{5}^{5}$ Murphy, J F, et al, Archives of Internal Medicine, 1976, 136, 670

${ }^{6}$ Luby, J P, et al, fournal of Infectious Diseases, 1974, 129, 511.

7 Ireland, P, et al, Archives of Internal Medicine, 1973, 132, 29.

${ }^{8}$ Millard, P R, et al, Transplantation, 1973, 16, 527.

9 Sparberg, M, Simon, N, and Del Greco, F, Gastroenterology, 1969, $\mathbf{5 7}, 439$.

10 Zarday, Z, et al, fournal of the American Medical Association, 1972, 222, 690.

11 Berne, T V, et al, Surgery, Gynecology and Obstetrics, 1975, 141, 171.

12 Galbraith, R M, et al, Lancet, 1975, 2, 528.

${ }^{13}$ Fiala, M, et al, fournal of Infectious Diseases, 1975, 132, 421.

14 Nagington, J, Cossart, Y E, and Cohen, B J, Lancet, 1977, 1, 558.

15 Andersen, H K, and Spencer, E S, Acta Medica Scandinavica, 1969, 186, 7 .

${ }^{16}$ Nagington, J, Fournal of Hygiene, 1971, 69, 645

17 Craighead, J E, Hanshaw, J B, and Carpenter, C B, fournal of the American Medical Association, 1967, 201, 725.

18 Greenberg, H B, et al, New England fournal of Medicine, 1976, 295, 517.

19 Pár, A, et al, Lancet, 1977, 1, 702.

${ }^{20}$ Bassendine, M F, et al, Gut, 1978, 19, A991 (abstract).

${ }^{21}$ Dickerman, R M, et al, Surgery, 1978, 84, 322.

22 Rashid, A, et al, Transactions of the American Society for Artificial Internal Organs, 1977, 23, 433.

23 Shons, A R, et al, New England fournal of Medicine, 1977, 296, 1169.

24 Ponticelli, C, et al, New England fournul of Medicine, 1977, 296, 1170.

${ }^{25}$ Rashid, A, et al, New England fournal of Medicine, 1977, 296, 1170.

26 Toussaint, C, New England Fournal of Medicine, 1977, 296, 1171.

27 London, W T, et al, New England Fournal of Medicine, 1977, 296, 241.

${ }^{28}$ Berne, ' T V, Fitzgibbons, T J, and Silberman, H, Transplantation, 1977, 24, 412

29 Fine, R N, et al, Annals of Surgerv, 1977, 185, 411.

30 Opelz, G, and Terasaki, P I, Transplantation, 1978, 25, 159.

31 Pirson, Y, Alexandre, G V P, and de Strihou, C V Y, New England fournal of Medicine, 1977, 296, 194.

32 Pirson, Y, Alexandre, G, and de Strihou, C V Y, New England fournal of Medicine, 1977, 296, 1171.

\section{Digoxin in sinus rhythm}

Since digitalis glycosides were introduced into clinical practice some 200 years ago controversy has continued over the indications for their use. Few physicians would argue with the statement that digoxin is singularly effective for controlling ventricular rate in patients with supraventricular tachyarrhythmias such as atrial fibrillation. Nevertheless, its use as an inotropic agent in patients with heart failure is being questioned with increasing frequency. ${ }^{12}$

Some $20 \%$ of all patients admitted to hospital with a medical (as opposed to surgical) illness are given digoxin. ${ }^{3}$ Toxic effects are seen in some $20 \%$ to $35 \%{ }^{45}$ of these patients. Our increased knowledge about the pharmacokinetics of digoxin together with the use of plasma concentration estimations may improve this figure. Even so, some have doubted the value of plasma digoxin concentrations, ${ }^{6} 7$ particularly for the diagnosis of toxicity, and most of the prescribing aids have proved too complicated for use at the bedside, especially in general practice. ${ }^{89}$ The elderly patient and those patients with impaired renal function remain at the greatest risk of developing digitalis toxicity.

Hence not surprisingly the initial indications for treatment with digoxin have been questioned, particularly in patients with heart failure who are in sinus rhythm. The aim of giving them digitalis is to increase myocardial contractility, but this is only one of the determinants of cardiac performance and preload (venous filling pressure), afterload (peripheral vascular resistance), and heart rate may all require separate attention. ${ }^{10}$ Many doctors think that the widespread use of potent diuretics which will reduce preload by removing salt and water has reduced the need for digoxin. Moreover, vasodilator drugswhich may reduce afterload as well as preload-have been shown to be of value in treating congestive heart failure. ${ }^{11} 12$ This approach, at present more popular in America than in Europe, is likely to be used more frequently and to erode the indications for digitalis even further.

Undoubtedly many patients are taking digoxin unnecessarily as long-term treatment. Furthermore, some $40-50 \%$ of patients for whom digoxin has been prescribed are not taking it properly. ${ }^{1314}$ Several studies have recently reported that digoxin can be withdrawn from the therapeutic regimen of between $75 \%$ and $94 \%$ patients in whom the initial indication for digoxin was congestive heart failure, without ill effect. ${ }^{15-19}$ Most of these patients were in sinus rhythm, and those whose serum digoxin concentration was less than $0.8 \mathrm{ng} / \mathrm{ml}$ (the therapeutic range is $0.8-2.0 \mathrm{ng} / \mathrm{ml}$ ) were least likely to deteriorate when the drug was stopped. Of the 28 patients in sinus rhythm whose plasma digoxin concentration was in the therapeutic range, however, only two developed a recurrence of congestive heart failure when digoxin was stopped. ${ }^{219}$

We have reasonable evidence that, used in the short term, digoxin has an inotropic effect in patients in sinus rhythm with congestive heart failure. ${ }^{20-23}$ Nevertheless, experts still disagree about the long-term use of digoxin in these patients, and whether its inotropic effect persists. The problem has been clarified by two recent studies. McHaffie and his colleagues studied six patients who were taking digoxin and diuretics for congestive heart failure of myocardial origin. ${ }^{19}$ All were in sinus rhythm and had serum concentrations of digoxin in the therapeutic range. After elimination of oedema and achievement of a "dry" basal weight, exercise tests were performed before and at periods after withdrawal of digoxin treatment. No change in symptoms, exercise capacity, respiratory quotient, or sense of well-being was noted when digoxin was stopped. Johnston and McDevitt have also withdrawn digoxin from a group of 22 patients in sinus rhythm in whom the pre-ejection period/left ventricular ejection time ratio was measured as an index of left ventricular function. ${ }^{2}$ In only two of the 17 patients who remained in sinus rhythm was there evidence of reduced left ventricular performance after stopping digoxin, and both patients had clinical heart failure.

Hence in most patients in sinus rhythm digoxin has no long-term stimulatory action on the heart. Nevertheless, the occasional patient will deteriorate clinically: in one study nearly $35 \%$ of 46 patients appeared to relapse on substituting placebo for their digoxin. ${ }^{16}$ In the long term, particularly in the elderly with their increased risks of toxicity, the doctor should consider withdrawing digoxin treatment. If he does he should keep a careful watch for signs and symptoms of deterioration over the next few weeks. Hence a rational recommendation is to give adequate diuretic treatment as the first approach to patients with heart failure who are in sinus rhythm. Digoxin should then be added if the symptoms or signs persist.

${ }^{1}$ Guz, A, and McHaffie, D, Clinical Science and Molecular Medicine, 1978, 55, 417 .

2 Johnston, G D, and McDevitt, D G, Lancet, 1979, 1, 567.

${ }^{3}$ Shapiro, S, et al, fournal of Chronic Diseases, 1969, 22, 361.

${ }^{4}$ Smith, T W, American fournal of Medicine, 1975, 58, 470. 
5 Ogilvie, R I, and Ruedy, J, Canadian Medical Association fournal, 1967, 97, 1450.

${ }^{6}$ Ingelfinger, J A, and Goldman, P, New England fournal of Medicine, 1976, $294,867$.

7 Lasagna, L, New England fournal of Medicine, 1976, 294, 898.

8 Aronson, J K, British fournal of Clinical Pharmacology, 1978, 5, 55.

- Peek, C C, et al, New England fournal of Medicine, 1973, 289, 441.

10 Cohn, J N, Fournal of the American Medical Association, 1974, 229, 1911.

11 Cohn, J N, and Franciosa, J A, New England fournal of Medicine, 1977, 297, 27.

12 Cohn, J N, and Franciosa, J A, New England fournal of Medicine, 1977, 297, 254.

13 Johnston, G D, Kelly, J G, and McDevitt, D G, British Heart fournal, $1978,40,1$.

14 Johnston, G D, and McDevitt, D G, British fournal of Clinical Pharmacology, 1978, 6, 339 .

15 Dall, J L C, British Medical fournal, 1970, 2, 705.

16 Dobbs, S M, Kenyon, W I, and Dobbs, R J, British Medical fournal, $1977,1,749$.

17 Hull, S M, and Mackintosh, A, Lancet, 1977, 2, 1054.

18 Liverpool Therapeutics Group, British Medical fournal, 1978, 2, 673.

${ }^{19}$ McHaffie, D, et al, Quarterly fournal of Medicine, 1978, 47, 401.

${ }^{20} \mathrm{Smith}, \mathrm{T}$ W, and Haber, E, New England fournal of Medicine, 1973, 289, 945.

${ }^{21}$ Smith, T W, and Haber, E, New England Fournal of Medicine, 1973, 289, 1010

${ }^{22}$ Smith, T W, and Haber, E, New England fournal of Medicine, 1973, 289, 1063.

${ }^{23}$ Smith, T W, and Haber, E, New England fournal of Medicine, 1973, 289, 1125.

\section{Rheumatoid arthritis and the gut}

Despite the widespread suspicion that micro-organisms may be implicated in the pathogenesis of rheumatoid arthritis they have not been found in the affected tissues. In consequence the part they play is assumed to be limited to that of an inciting agent for a chain of events. Even in this there is no evidence to incriminate any particular organism nor is there any agreement whether the disease persists because the immune response is abnormal and self-perpetuating or because the postulated micro-organisms persist-or, indeed, both.

Work on the enteropathic arthropathies has led to several promising lines of investigation. A peripheral polyarthritis (distinct from the spinal form) is a common complication of intestinal disorders including ulcerative colitis, ${ }^{1}$ Crohn's disease, ${ }^{2}$ and Whipple's disease ${ }^{3}$; it may also be a rare complication of jejunal bypass surgery for obesity. ${ }^{4}$ These and other reactive arthropathies differ from rheumatoid arthritis in some important ways: they tend to be self-limiting, wax and wane with the primary disorder, and do not show erosive joint damage. These arthropathies may not, however, share a common mechanism, and among the possibilities that have been considered are altered absorption of antigenic material through a damaged gut mucosa, formation and later deposition of soluble immune complexes, and abnormalities of cellmediated immunity.

A recent and thought-provoking development has been the finding of an association between reactive polyarthritis and bowel infections with Yersinia enterocolitica, the relevant point being that nearly $90 \%$ of such patients have the genetic marker HLA B27. ${ }^{5}$ An even higher proportion of patients with arthritis associated with Salmonella infections have the same marker; there is also a close association between Reiter's disease and the presence of HLA B27, especially in patients with sacroiliitis. ${ }^{6}$ The clear implication is that the immuno- pathological reaction to antigens is determined geneticallyor, put another way by Ziff, ${ }^{7}$ certain gut orgahisms may possess or acquire common or cross-reacting antigens which can produce an "inciting" immune response in HLA-B27positive individuals. In ankylosing spondylitis (also closely associated with HLA $\mathrm{B} 27^{8}$ ) the mechanism may be different: for the factor triggering off many of the inflammatory phenomena may be not an exogenous infection but an abnormal gut flora, specifically a high faecal count of Klebsiella pneumoniae. ${ }^{9}$

The hypothesis that arthropathies could be indirect consequences of an alteration in the resident bacterial population in the gut may not be applicable to ulcerative colitis, in which the gut flora is apparently not much altered. ${ }^{10}$ It may, however, apply to rheumatoid arthritis. Either an abnormal flora (defined as a high count of Clostridium perfringens or the production of an excess alpha-toxin) was found in $67 \%$ of patients with rheumatoid arthritis. ${ }^{11}$ Moreover, after being fed a diet high in fish protein those pigs which developed polyarthritis and nodules-the animal model perhaps most closely resembling human rheumatoid arthritis-did so soon after greatly increased numbers of $C l$ perfringens had appeared in the faeces. ${ }^{12}$ As to the genetic susceptibility in man, despite earlier denials it is now clear that an HLA association with rheumatoid arthritis does exist-namely, HLA DW4 $4^{13}$ and, more closely, HLA DrW4. ${ }^{14}$

We have little evidence to support dietary abnormalities in the aetiology of rheumatoid arthritis, but the gastrointestinal milieu may not be normal and this could possibly encourage changes in bowel flora. Resting and maximal gastric secretory volumes are reduced by more than half, ${ }^{15}$ though the concentration of pepsin is not increased in compensation; and malabsorption, usually mild, has been found in up to $40 \%$ of a few patients with rheumatoid arthritis. ${ }^{16}$ Following Scandinavian work, one group ${ }^{17}$ has claimed success from treatment of rheumatoid arthritis with sulphasalazine, which does alter the gut flora. ${ }^{18}$ Their measures of success were changes in serum $\mathrm{C}$-reactive protein and the sedimentation rate, but the study did not include a control group of untreated patients. If, indeed, sulphasalazine is effective in rheumatoid arthritis could it be through its antibacterial properties and not, as they suggested, its immunological effect? An attractive aspect of the hypothesis that rheumatoid arthritis may be an arthropathy linked to causes in the gut is that it would explain the apparent persistence of an antigen.

1 Wright, V, and Watkinson, G, British Medical fournal, 1965, 2, 670.

2 Van Patter, W N, et al, Gastroenterology, 1954, 26, 347.

${ }^{3}$ Caughey, D E, and Bywaters, E G L, Annals of the Rheumatic Diseases, 1963, 22, 327.

4 Wands, J R, et al, New England fournal of Medicine, 1976, 294, 121.

5 Aho, K, et al, Annals of the Rheumatic Diseases, 1975, 24, suppl 1, p 29.

${ }^{6}$ Wright, V, in Copeman's Textbook of the Rheumatic Diseases, 5th edn, ed J T Scott, p 560. Edinburgh, Churchill, 1978.

$7 \mathrm{Ziff}, \mathrm{M}$, in Infection and Immunology in Rheumatic Diseases, ed D C Dumonde, p 627. Oxford, Blackwell, 1976.

8 Brewerton, D A, et al, Lancet, 1973, 2, 996.

9 Ebringer, R, Cawdell, D, and Ebringer, A, British Medical fournal, 1979, $1,383$.

${ }_{10}$ Keighley, M R B, et al, Gut, 1978, 19, 1099.

11 Olhagen, B, and Mansson, I, Acta Medica Scandinavica, 1968, 184, 395.

12 Mansson, I, et al, Clinical and Experimental Immunology, 1971, 9, 677.

13 Stastny, P, fournal of Clinical Investigation, 1976, 57, 1148.

14 Bodmer, J G, et al, Tissue Antigens, 1977, 10, 197.

15 Olhagen, B, in Infection and Immunology in Rheumatic Diseases, ed D C Dumonde, p 141. Oxford, Blackwell, 1976.

${ }^{16}$ Dyer, N H, Kendall, M J, and Hawkins, C F, Annals of the Rheumatic Diseases, 1971, 30, 626.

17 McConkey, B, et al, Agents and Actions, 1978, 8, 438.

18 West, B, et al, Gut, 1974, 15, 960. 